\title{
Enhancement of Two-Dimensional Electron-Gas Properties by Zn Polar ZnMgO/MgO/ZnO Structure Grown by Radical-Source Laser Molecular Beam Epitaxy
}

\author{
Li Meng, ${ }^{1,2,3}$ Jingwen Zhang, ${ }^{1,2,3}$ Qun Li, ${ }^{1,2,3}$ and Xun Hou ${ }^{1}$ \\ ${ }^{1}$ Key Laboratory of Photonics Technology for Information, Xian Jiaotong University, Xian, Shaanxi 710049, China \\ ${ }^{2}$ Key Laboratory for Physical Electronics and Devices under Ministry of Education, Xian Jiaotong University, Xian, \\ Shaanxi 710049, China \\ ${ }^{3}$ Joint Laboratory of Functional Materials and Devices for Informatics, Xian Jiaotong University and Institute of Semiconductors, \\ CAS, Xian, Shaanxi 710049, China
}

Correspondence should be addressed to Jingwen Zhang; jwzhang@mail.xjtu.edu.cn

Received 19 January 2015; Accepted 9 March 2015

Academic Editor: Meiyong Liao

Copyright (C) 2015 Li Meng et al. This is an open access article distributed under the Creative Commons Attribution License, which permits unrestricted use, distribution, and reproduction in any medium, provided the original work is properly cited.

A $\mathrm{Zn}$ polar $\mathrm{ZnMgO} / \mathrm{MgO} / \mathrm{ZnO}$ structure with low $\mathrm{Mg}$ composition $\mathrm{Zn}_{1-x} \mathrm{Mg}_{x} \mathrm{O}$ layer $(x=0.05)$ grown on a-plane (11-20) sapphire by radical-source laser molecular beam epitaxy was reported. The insertion of a thin $(1 \mathrm{~nm}) \mathrm{MgO}$ layer between $\mathrm{ZnMgO}$ and $\mathrm{ZnO}$ layers in the $\mathrm{ZnMgO} / \mathrm{ZnO}$ 2DEG structures results in an increase of 2DEG sheet density and affects electron mobility slightly. The carrier concentration reached a value as high as $1.1 \times 10^{13} \mathrm{~cm}^{-2}$, which was confirmed by $C-V$ measurements. A high Hall mobility of $3090 \mathrm{~cm}^{2} / \mathrm{Vs}$ at $10 \mathrm{~K}$ and $332 \mathrm{~cm}^{2} / \mathrm{Vs}$ at RT was observed from $\mathrm{Zn}_{0.95} \mathrm{Mg}_{0.05} \mathrm{O} / \mathrm{MgO} / \mathrm{ZnO}$ heterostructure. The choice of the thickness of $\mathrm{MgO}$ was discussed. The dependence of carrier sheet density of 2DEG on ZnMgO layer thickness was calculated in theory and the theoretical prediction and experimental results agreed well.

\section{Introduction}

$\mathrm{ZnO}$ and its heterostructures, which have several advantages including a high saturation velocity [1], a large conduction band offset for $\mathrm{ZnMgO} / \mathrm{ZnO}$ heterostructures [2], and the possibility to form a high-density two-dimensional electron-gas (2DEG) [3], have great potential for highfrequency and high-power device applications. So far, the formation of $2 \mathrm{DEG}$ at $\mathrm{Zn}$ polar $\mathrm{Zn}_{1-x} \mathrm{Mg}_{x} \mathrm{O} / \mathrm{ZnO}$ interface has been observed by a few groups using molecular beam epitaxy (MBE) [4-8], pulse laser deposition (PLD) techniques [9], metal-organic vapor phase epitaxy (MOVPE) [10], and RF sputtering [11]. However, in low $\mathrm{Mg}$ composition $\mathrm{Zn}_{1-x} \mathrm{Mg}_{x} \mathrm{O} / \mathrm{ZnO}$ heterostructures $(x<0.1)$ high electron mobility can be observed but with very low 2DEG sheet density $\left(n<10^{12} \mathrm{~cm}^{-2}\right)$ [12], and in high $\mathrm{Mg}$ composition $\mathrm{Zn}_{1-x} \mathrm{Mg}_{x} \mathrm{O} / \mathrm{ZnO}$ heterostructures $(x>0.1), 2$ DEG sheet density reached a considerable value $\left(10^{12} \sim 10^{13} \mathrm{~cm}^{-2}\right)$ but electron mobility is still deeply affected by alloy disorder scattering, especially at low temperatures. In addition the obtained mobility in previous papers was lower than $250 \mathrm{~cm}^{2} / \mathrm{Vs}$ at RT [13]. It has been reported that modified AlGaN/AlN/GaN structures, which employ a thin AlN interfacial layer between $\mathrm{AlGaN}$ and GaN layers, show higher 2DEG properties than those of conventional AlGaN/GaN structures. This is reported to be a result of the reduction of alloy disorder scattering due to the suppression of carrier penetration from the GaN channel into the AlGaN layer [14-17]. However, the inserting of $\mathrm{MgO}$ into $\mathrm{ZnMgO} / \mathrm{ZnO}$ structure has never been reported. In this work, we report a $\mathrm{Zn}$ polar $\mathrm{ZnMgO} / \mathrm{MgO} / \mathrm{ZnO}$ structure to enhance twodimensional electron-gas properties and discuss the dependence of carrier sheet density of $2 \mathrm{DEG}$ on $\mathrm{ZnMgO}$ layer thickness which was calculated in theory and the theoretical prediction and experimental results agreed well. 


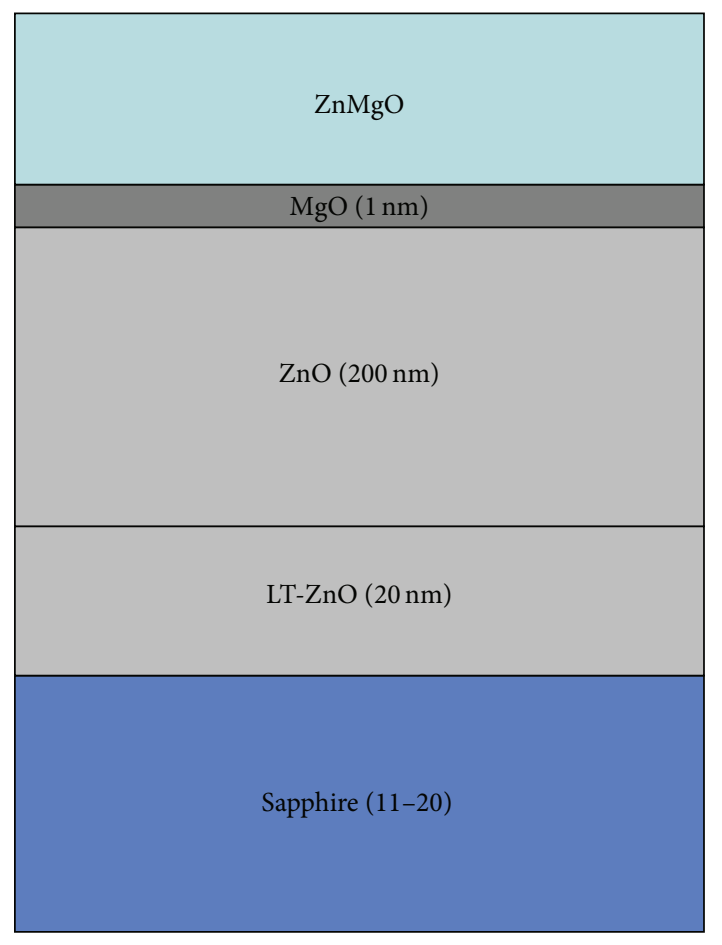

(a)

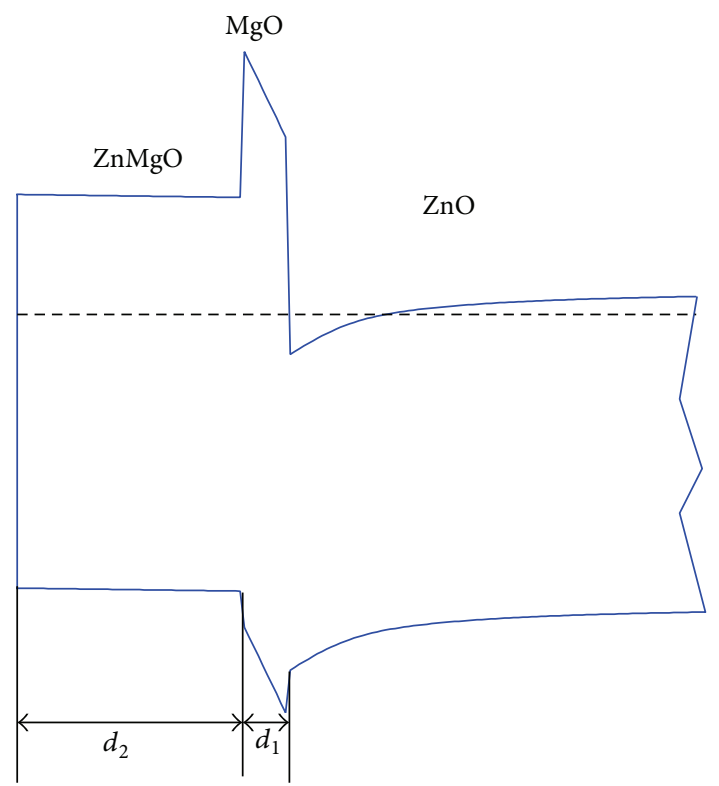

(b)

Figure 1: Layer structure (a) and band diagram (b) for a $\mathrm{Zn}$ polar $\mathrm{ZnMgO} / \mathrm{MgO} / \mathrm{ZnO}$ heterostructure. The growth direction is $<0001>$ for Zn polarity.

\section{Materials and Methods}

$\mathrm{Zn}$ polar $\mathrm{ZnMgO} / \mathrm{ZnO}$ and $\mathrm{ZnMgO} / \mathrm{MgO} / \mathrm{ZnO}$ heterostructures were all grown on sapphire (11-20) substrates by radicalsource laser molecular beam epitaxy (RS-LMBE) system (Shenyang Scientific Instrument Co., Ltd., Chinese Academy of Sciences (SKY)). The $5 \mathrm{~N}$ purity of $\mathrm{ZnO}$ target was vaporized by $\mathrm{KrF}$ excimer laser (Lambda Physik, COMPex $102,248 \mathrm{~nm}, 1-20 \mathrm{~Hz}, 100 \mathrm{~mJ})$. At first, the substrates were treated by nitrogen plasma, which was ionized by radiofrequency (rf) plasma source (Oxford Applied Research, HD25) at $700^{\circ} \mathrm{C}$ for $1 \mathrm{~h}$ to obtain nitrogen polarity surface and control the growth of single-domain $\mathrm{Zn}$ polar $\mathrm{ZnO}$ film [18]. The growth was conducted in an oxygen pressure of $10^{-3} \mathrm{~Pa}$. A $20 \mathrm{~nm}$ thick low temperature- (LT-) ZnO buffer layer was deposited at $250^{\circ} \mathrm{C}$. Secondly, a $200 \mathrm{~nm}$ undoped $\mathrm{ZnO}$ layer was deposited at $700^{\circ} \mathrm{C}$. Finally, an undoped $\mathrm{ZnMgO}$ layer was grown at $400^{\circ} \mathrm{C}$. For $\mathrm{ZnMgO} / \mathrm{MgO} / \mathrm{ZnO}$ heterostructures (Figure 1(a)), the $\mathrm{MgO}$ was deposited before the growth of $\mathrm{ZnMgO}$ layer under same condition with $\mathrm{ZnMgO}$ layer. The crystalline qualities of the thin films were studied by Philips X'Pert PW3040 high resolution X-ray diffraction (XRD) system using $\mathrm{Cu} \mathrm{K} \alpha(\lambda=0.15406 \mathrm{~nm})$. The growth evolution of $\mathrm{MgO}$ layer and the choice of its thickness were investigated by the streaky patterns of the reflection high-energy electron diffraction (RHEED). The $\mathrm{Mg}$ composition $(x)$ was determined from the reflectance measurement of the exciton band gap energy of $\mathrm{Zn}_{1-x} \mathrm{Mg}_{x} \mathrm{O}$ using the equation $E_{g}(x)=E_{g}(0)+2.145 x$ [19]. The crystal polarity was determined based on differences in etching-rate between $\mathrm{Zn}$ polar and $\mathrm{O}$-polar samples. Chemical wet etching was carried out using $0.01 \mathrm{M}$ hydrochloric acid solution at room temperature, for etching-rate measurements [20]. The capacitance-voltage $(C-V)$ measurement was performed by using mercury contacts. The electrical properties were examined by Lake Shore 7707A Hall mobility system in a van der Pauw configuration with a magnetic-field of $1000 \mathrm{G}$.

\section{Results and Discussion}

3.1. The Thickness of the MgO Insert Layer. To optimize the $\mathrm{MgO}$ thickness and make sure that the $\mathrm{MgO}$ has grown as wurtzite structure, the growth evolution of $\mathrm{MgO}$ layer was investigated by RHEED pattern, shown as in Figure 2. Initially, the $\mathrm{MgO}$ layer grew 2-dimensionally on $\mathrm{c}-\mathrm{ZnO}$ as the thickness was 0.5 and $1 \mathrm{~nm}$ in Figures 2(a) and 2(b). Then the growth mode of $\mathrm{MgO}$ layer changes from 2-dimensional to 3-dimensional. When the $\mathrm{MgO}$ thickness was $1.5 \mathrm{~nm}$, the RHEED spots appeared (Figure 2(c)), which suggests that the crystal structure of the $\mathrm{MgO}$ layer changes with increasing layer thickness. Therefore, in this paper, a $1 \mathrm{~nm} \mathrm{MgO}$ layer was chosen.

3.2. Structural Property. Figure 3 shows the XRD spectra for the grown $\mathrm{ZnMgO} / \mathrm{MgO} / \mathrm{ZnO}$ structure on sapphire substrate. Because of the low concentration of $\mathrm{Mg}$ in the $\mathrm{ZnMgO}$ layer, the $\mathrm{ZnO}$ (0002) peak and $\mathrm{ZnMgO}$ (0002) are overlapped. The crystal quality of the $\mathrm{Zn}_{0.95} \mathrm{Mg}_{0.05} \mathrm{O} / \mathrm{MgO} / \mathrm{ZnO}$ 


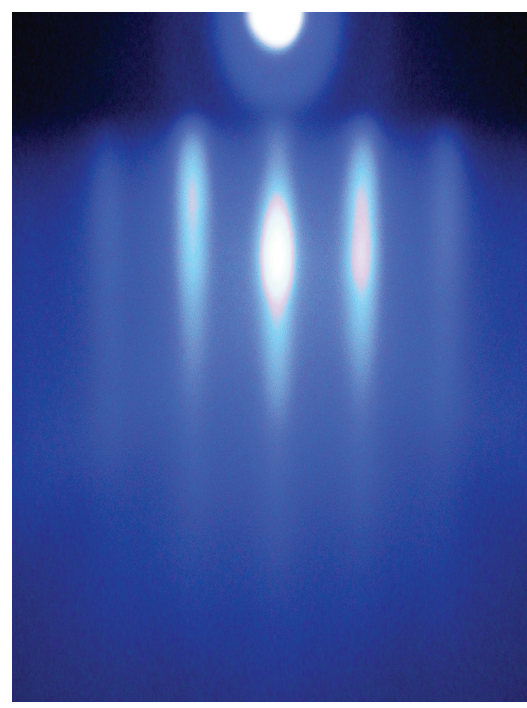

(a)

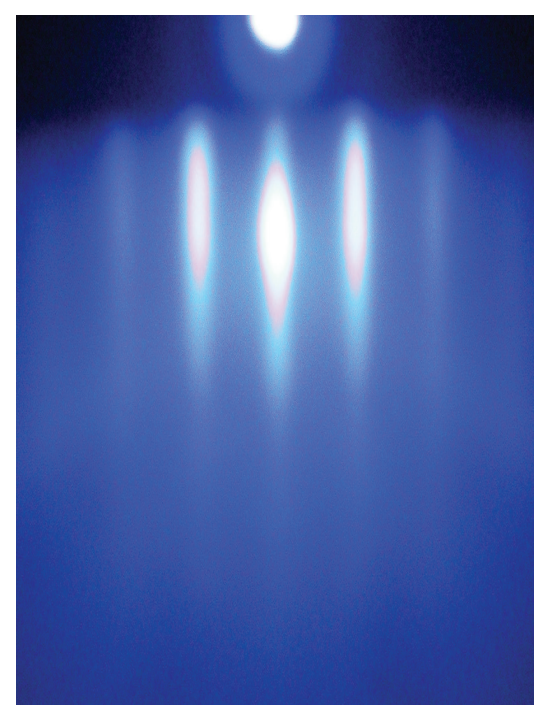

(b)

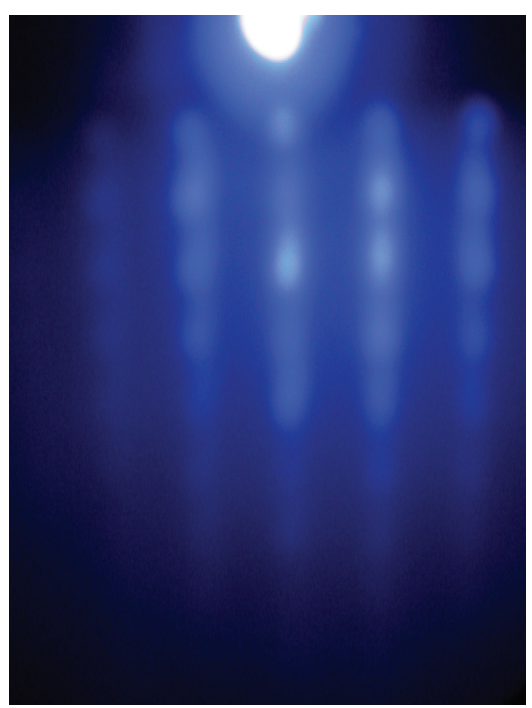

(c)

Figure 2: The evolution of RHEED pattern during growth of the MgO layer. The direction of $\mathrm{MgO}$ is $<11-20>$. (a) The thickness of the MgO buffer layer is $0.5 \mathrm{~nm}$; (b) thickness of $\mathrm{MgO}=1 \mathrm{~nm}$; and (c) thickness of $\mathrm{MgO}=1.5 \mathrm{~nm}$.

structure was characterized by a cross-sectional TEM image (JEM-2100F). A typical image recorded near the $\mathrm{ZnMgO} / \mathrm{MgO} / \mathrm{ZnO}$ interface is shown in the inset of Figure 3. The interface could not be detected in the TEM micrograph clearly, which suggests that the structure has a high degree of crystalline quality. The $\mathrm{MgO}$ has no phase transition from wurtzite structure to rock salt structure. High electron mobility will benefit from the enhanced structure and crystal quality. It also can be observed that the $\mathrm{MgO}$ interfacial layer is grown with a thickness of approximately $1 \mathrm{~nm}$, which corresponds to the designed thickness.

3.3. Electrical Property. Figure 4 displays carrier density derived from capacitance as a function of distance from the top surface for the $\mathrm{Zn}_{0.95} \mathrm{Mg}_{0.05} \mathrm{O} / \mathrm{ZnO}$ and
$\mathrm{Zn}_{0.95} \mathrm{Mg}_{0.05} \mathrm{O} / \mathrm{MgO} / \mathrm{ZnO}$ structures, and both of the thicknesses of $\mathrm{Zn}_{0.95} \mathrm{Mg}_{0.05} \mathrm{O}$ layers are $100 \mathrm{~nm}$. It shows that high concentration 2DEG was confined at the interface. Formation of 2DEG at the interface was demonstrated by the features. Comparing with $\mathrm{Zn}_{0.95} \mathrm{Mg}_{0.05} \mathrm{O} / \mathrm{ZnO}$ structure, a sharp 2DEG peak is shown around interface in $\mathrm{Zn}_{0.95} \mathrm{Mg}_{0.05} \mathrm{O} / \mathrm{MgO} / \mathrm{ZnO}$ structure without penetration into the $\mathrm{Zn}_{1-x} \mathrm{Mg}_{x} \mathrm{O}$ layer, which behaves similarly with previous report about AlGaN/AlN/GaN [14]. From these results, it can be concluded that the thin $\mathrm{MgO}$ interfacial layer effectively suppresses carrier penetration into the $\mathrm{ZnMgO}$ layer and enhances the confinement of 2DEG in $\mathrm{ZnO}$ channel. In addition, a sheet carrier concentration of 1.1 $\times 10^{13} \mathrm{~cm}^{-2}$ was observed in the $\mathrm{Zn}_{0.95} \mathrm{Mg}_{0.05} \mathrm{O} / \mathrm{MgO} / \mathrm{ZnO}$ structure with $20 \mathrm{~nm}$ thick $\mathrm{Zn}_{0.95} \mathrm{Mg}_{0.05} \mathrm{O}$ layer confirmed by 


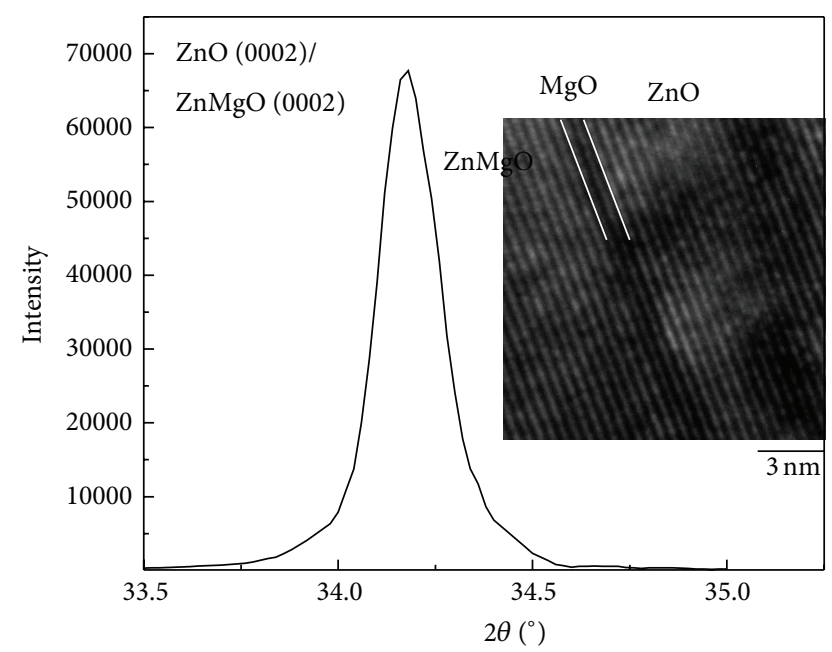

Figure 3: The XRD spectra for the grown $\mathrm{ZnMgO} / \mathrm{MgO} / \mathrm{ZnO}$ structure; the inset is the cross-sectional TEM image of a $\mathrm{ZnMgO} / \mathrm{MgO} / \mathrm{ZnO}$ film.

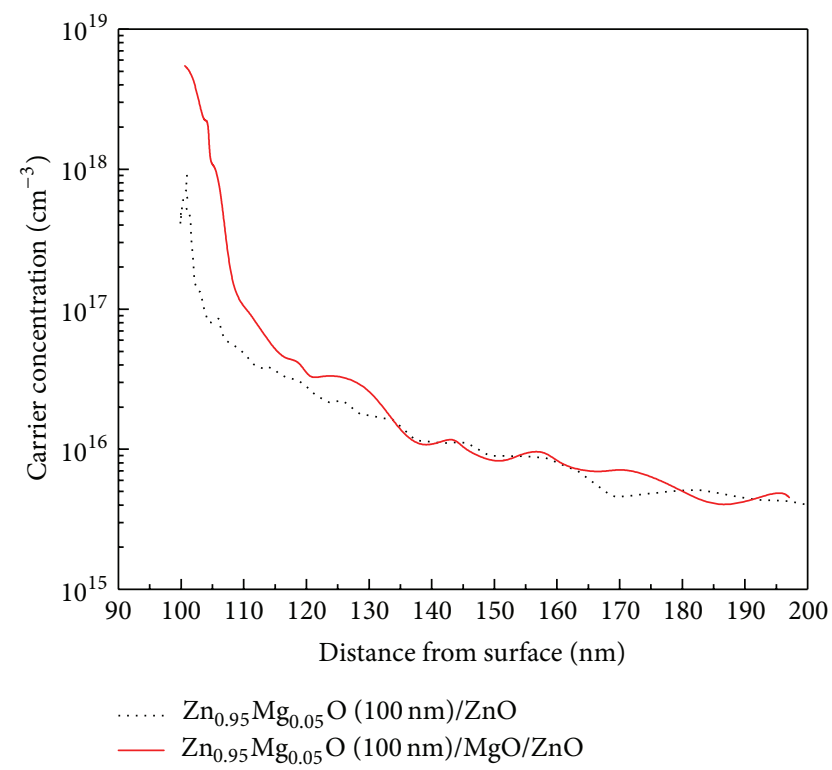

Figure 4: $C-V$ depth profiling of the 2DEG and net donor concentration in the $\mathrm{Zn}_{0.95} \mathrm{Mg}_{0.05} \mathrm{O} / \mathrm{ZnO}$ and $\mathrm{Zn}_{0.95} \mathrm{Mg}_{0.05} \mathrm{O} / \mathrm{MgO} / \mathrm{ZnO}$ structures.

$C-V$ measurement. 2DEG of $\mathrm{Zn}_{0.95} \mathrm{Mg}_{0.05} \mathrm{O} / \mathrm{ZnO}$ structure with $20 \mathrm{~nm}$ thick $\mathrm{Zn}_{0.95} \mathrm{Mg}_{0.05} \mathrm{O}$ layer was not observed by $C-V$. Owing to the low $\mathrm{Mg}$ content and thickness of $\mathrm{ZnMgO}$ barrier layer, the conduction band offset was small and the providing of electron was not enough to format 2DEG.

Table 1 shows the typical values of Hall mobility $(\mu)$ and $2 \mathrm{DEG}$ density $(n)$ measured at $300 \mathrm{~K}$ and $10 \mathrm{~K}$ for $\mathrm{ZnMgO} / \mathrm{ZnO}$ structures with or without $\mathrm{MgO}$ interfacial layers. From Table 1, it is clearly seen that the Hall mobility was increased by the insertion of $\mathrm{MgO}$ interfacial layers. In particular, the $\mathrm{Zn}_{0.95} \mathrm{Mg}_{0.05} \mathrm{O}(20 \mathrm{~nm}) / \mathrm{MgO} / \mathrm{ZnO}$ heterostructure showed very high Hall mobility of $332 \mathrm{~cm}^{2} / \mathrm{Vs}$
TABLE 1: Typical Hall mobility $(\mu)$ and 2DEG density $(n)$ measured at $300 \mathrm{~K}$ and $10 \mathrm{~K}$ for $\mathrm{ZnMgO} / \mathrm{ZnO}$ structures with or without $\mathrm{MgO}$ interfacial layers.

\begin{tabular}{lccccc}
\hline Structure & $\begin{array}{c}\mathrm{ZnMgO} \\
\text { thickness }(\mathrm{nm})\end{array}$ & $300 \mathrm{~K}$ & $10 \mathrm{~K}$ & $300 \mathrm{~K}$ & $10 \mathrm{~K}$ \\
\hline $\mathrm{ZnMgO} / \mathrm{MgO} / \mathrm{ZnO}$ & 20 & 25 & 22 & 332 & 3090 \\
$\mathrm{ZnMgO} / \mathrm{ZnO}$ & 20 & 1.5 & 0.2 & 137 & 130 \\
$\mathrm{ZnMgO} / \mathrm{MgO} / \mathrm{ZnO}$ & 100 & 2.2 & 1.9 & 321 & 2480 \\
$\mathrm{ZnMgO} / \mathrm{ZnO}$ & 100 & 0.2 & 0.4 & 215 & 2360 \\
\hline
\end{tabular}

at RT and $3090 \mathrm{~cm}^{2} / \mathrm{Vs}$ at $10 \mathrm{~K}$. Figure 5 shows the results of temperature-dependent Hall measurements. The electron mobility of $\mathrm{Zn}_{0.95} \mathrm{Mg}_{0.05} \mathrm{O}(100 \mathrm{~nm}) / \mathrm{ZnO}$ and $\mathrm{Zn}_{0.95} \mathrm{Mg}_{0.05} \mathrm{O}$ $(100 \mathrm{~nm}$ and $20 \mathrm{~nm}) / \mathrm{MgO} / \mathrm{ZnO}$ structures increases with decreasing temperature, as shown in Figure 5(a). This trend is nearly identical to that reported for AlGaAs/GaAs [2123], AlGaN/GaN [24, 25], and $\mathrm{ZnMgO} / \mathrm{ZnO}$ heterostructure $[5,13]$, which is consistent with the existence of a $2 \mathrm{DEG}$ at the heterointerface. Compared with reported values for both $\mathrm{Zn}$ polar and $\mathrm{O}$-polar $\mathrm{ZnMg}(\mathrm{Mn}) \mathrm{O} / \mathrm{ZnO}$ heterostructures, the high mobility is obvious [11, 13, 26, 27]. The mobility of $\mathrm{Zn}_{0.95} \mathrm{Mg}_{0.05} \mathrm{O}(20 \mathrm{~nm}) / \mathrm{ZnO}$ structure changed similarly to a single $\mathrm{ZnO}$ thin film as the temperature was changing, which indicates no 2DEG was formatted because of thin barrier layer. By the insertion of $\mathrm{MgO}$ layer, a 2DEG was observed. The results agree well with the results of $C-V$ measurement. The high electron mobility of the $\mathrm{ZnMgO} / \mathrm{MgO} / \mathrm{ZnO}$ heterostructure was mainly attributed to the reduction of alloy disorder scattering. In Figure 5(b), the sheet carrier concentration of $\mathrm{Zn}_{0.95} \mathrm{Mg}_{0.05} \mathrm{O}(100 \mathrm{~nm}) / \mathrm{ZnO}$ and $\mathrm{Zn}_{0.95} \mathrm{Mg}_{0.05} \mathrm{O}$ $(100 \mathrm{~nm}$ and $20 \mathrm{~nm}) / \mathrm{MgO} / \mathrm{ZnO}$ structures changes little with increasing temperatures, indicating the good confinement of channel electrons. The insert of a thin $(1 \mathrm{~nm}) \mathrm{MgO}$ layer between $\mathrm{ZnMgO}$ and $\mathrm{ZnO}$ enhanced the sheet carrier concentration almost one order of magnitude. It also confirms the thin $\mathrm{MgO}$ enhanced the confinement effectively.

3.4. The Calculation and Experimental Results of the Dependence of Carrier Sheet Density of 2DEG on ZnMgO Layer Thickness. It is noted that the presence of strong polarizationinduced fields in both $\mathrm{MgO}$ and $\mathrm{ZnMgO}$ cap layers leads to a very interesting dependence of the $2 \mathrm{DEG}$ sheet density in $\mathrm{ZnMgO} / \mathrm{MgO} / \mathrm{ZnO}$ structures on $\mathrm{ZnMgO}$ cap thickness. The density of 2DEG decreases with increasing $\mathrm{ZnMgO}$ thickness. To discuss the behavior of $2 \mathrm{DEG}$ density changing with the thickness of $\mathrm{ZnMgO}$ layer in $\mathrm{ZnMgO} / \mathrm{MgO} / \mathrm{ZnO}$ structures, simple electrostatic analysis of the $\mathrm{Zn}_{1-x} \mathrm{Mg}_{x} \mathrm{O} / \mathrm{MgO} / \mathrm{ZnO}$ heterostructures yields the following expression for the $2 \mathrm{DEG}$ sheet density $[11,15,28-30]$ :

$$
n_{S}=\frac{1}{1+d_{1} / d_{2}}\left[\frac{+\sigma}{e}-\frac{\varepsilon_{0} \varepsilon}{d_{2}}\left(e \phi_{b}+E_{F}-\Delta E_{C}\right)\right],
$$

where the effect of $\mathrm{Zn}_{1-x} \mathrm{Mg}_{x} \mathrm{O}$ cap was approximately equal to a $\mathrm{ZnO}$ cap layer because of the low $\mathrm{Mg}$ composition and where $d_{1}$ ( $1 \mathrm{~nm}$ here) and $d_{2}$ are the thicknesses of the $\mathrm{MgO}$ and top $\mathrm{Zn}_{1-x} \mathrm{Mg}_{x} \mathrm{O}$ layer barrier layers, correspondingly, 


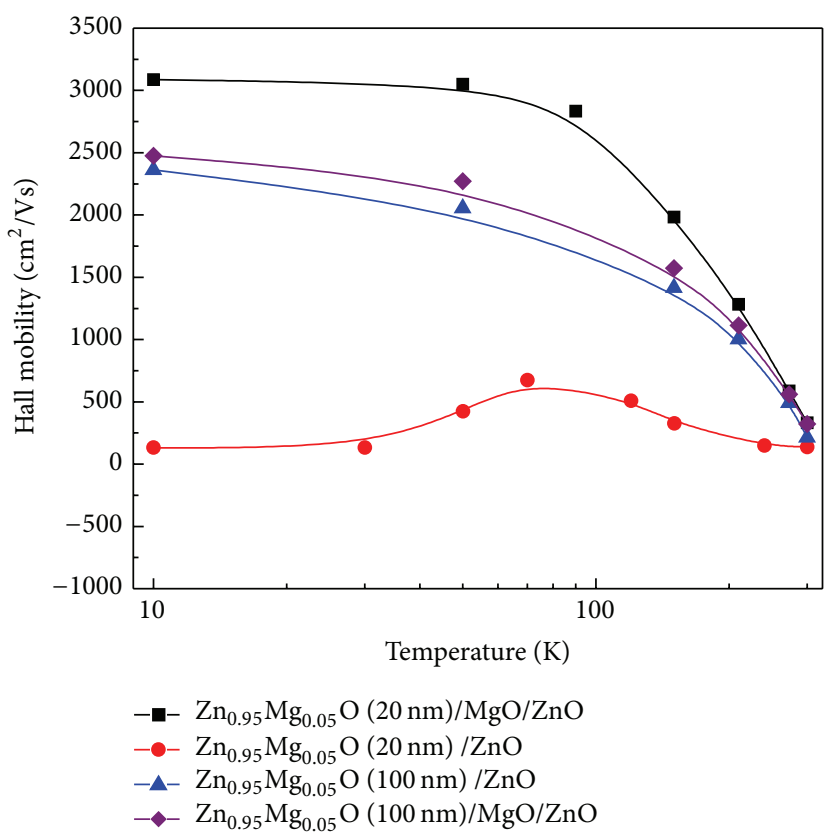

(a)

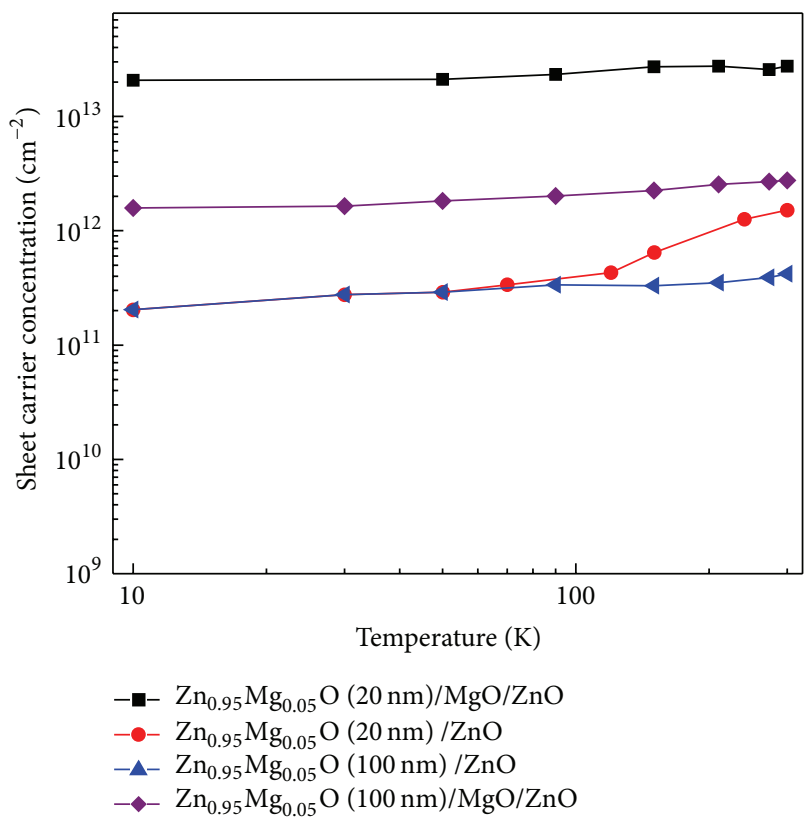

(b)

Figure 5: Temperature-dependent Hall measurements for $\mathrm{Zn}$ polar $\mathrm{Zn}_{0.95} \mathrm{Mg}_{0.05} \mathrm{O} / \mathrm{ZnO}$ and $\mathrm{Zn}_{0.95} \mathrm{Mg}_{0.05} \mathrm{O} / \mathrm{MgO} / \mathrm{ZnO}$ structures, mobility (a) and carrier concentration (b).

as shown in Figure 1(b); the surface potential $e \phi_{b}$ is assumed to be pinned at surface with a level of $0.8 \mathrm{eV}$ below $\mathrm{ZnO}$ conduction band edge. The conduction band offset $\Delta E_{C}$ is equal to $0.9 \times\left[E_{g}(\mathrm{MgO})-E_{g}(\mathrm{ZnO})\right][31]$. We approximate the Fermi level $E_{F}$ by the infinite triangular quantum well [23], which can be expressed as

$$
E_{F}=\left[\frac{9 \pi \hbar e^{2}}{\left(8 \varepsilon_{0} \sqrt{8 m^{*}}\right)} \frac{n_{S}}{\varepsilon}\right]^{2 / 3}+\frac{\pi \hbar^{2}}{m^{*} n_{S}},
$$

where the dielectric constant $\varepsilon$ is given as $(8.75+1.08 * 1)$ for the very thin wurtzite $\mathrm{MgO}$ [10]. The effective mass is taken to be $m^{*} \approx 0.26 m_{e} . \sigma$ is the polarization-induced charge density determined by the vector sum of the spontaneous polarization $\left(P_{\mathrm{SP}}\right)$ and the strain-induced piezoelectric polarization $\left(P_{\mathrm{PE}}\right)$ while there is no external field. We assume that the thin $\mathrm{MgO}$ layer is fully strained on $\mathrm{ZnO}$ and polarization constants vary linearly with $x$ composition. Thus, the dependence of total polarizations-induced charges in $\mathrm{MgO}$ layer can be expressed as $\sigma=0.029 x\left(\mathrm{C} / \mathrm{m}^{2}\right)(x=$ 1) [12]. Taking the tunneling of electrons from $\mathrm{MgO} / \mathrm{ZnO}$ channel to $\mathrm{Zn}_{1-x} \mathrm{Mg}_{x} \mathrm{O}$ layer into account, we modified $\sigma$ by a coefficient $v$, and then it can be expressed as

$$
\sigma=0.029 v\left(\mathrm{C} / \mathrm{m}^{2}\right), \quad(v=0 \sim 1) .
$$

For $v=0.1$, the calculated 2DEG density and experimental results were shown in Figure 6. The solid line is the calculated plot extracted from (1). The sheet carrier concentration decreases rapidly as the thickness of $\mathrm{ZnMgO}$ layer increases. The 2DEG density of the $\mathrm{Zn}_{0.95} \mathrm{Mg}_{0.05} \mathrm{O} / \mathrm{MgO} / \mathrm{ZnO}$

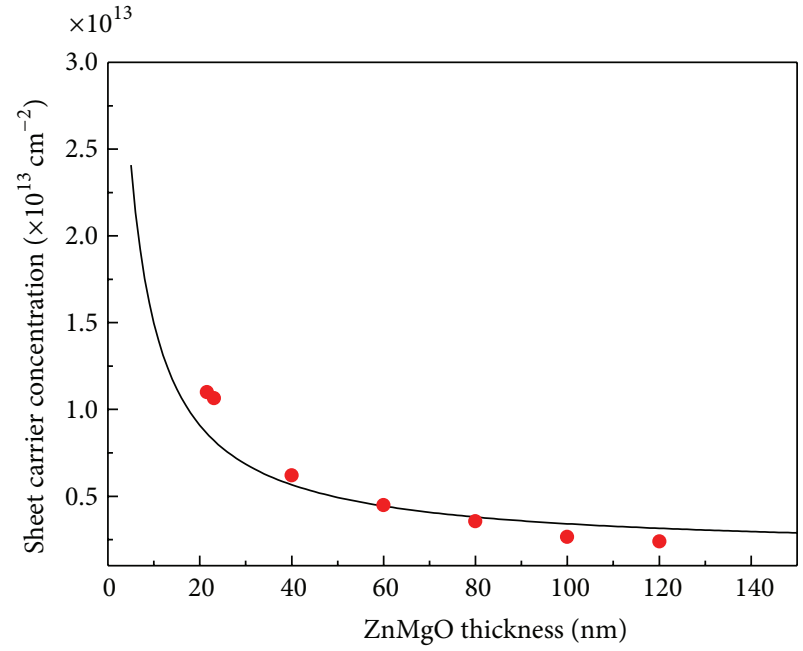

FIGURE 6: The dependence of sheet carrier concentration as a function of $\mathrm{ZnMgO}$ layer thickness.

structure with the layer thickness of $20 \mathrm{~nm}$ is $1.1 \times 10^{13} \mathrm{~cm}^{-2}$, and it becomes $2.4 \times 10^{12} \mathrm{~cm}^{-2}$ when the thickness is $120 \mathrm{~nm}$. The theoretical prediction and experimental results agreed well below $80 \mathrm{~nm}$, which confirmed the $\mathrm{ZnMgO}$ layers in $\mathrm{ZnMgO} / \mathrm{MgO} / \mathrm{ZnO}$ structure, to a certain extent, behaved similar to a $\mathrm{ZnO}$ cap layer. After the thickness became larger than 80 , the $2 \mathrm{DEG}$ density became lower than the calculated line. That is because the stress of the $\mathrm{ZnMgO}$ strain layer increases as the thickness increases, which results in the 
deterioration of crystal quality. There might be other reasons which need to be studied in the future.

We note that there is somewhat a discrepancy in the sheet carrier concentration values obtained by $C-V$ and Hall measurement. Since the data observed from Hall measurement includes the contribution of bulk carrier, the value was higher than the true value.

\section{Conclusion}

In summary, formation of a $2 \mathrm{DEG}$ was confirmed for $\mathrm{Zn}$ polar $\mathrm{ZnMgO} / \mathrm{ZnO}$ heterostructures with low $\mathrm{Mg}$ composition $(x=0.05)$. The enhancement of $2 \mathrm{DEG}$ concentration and mobility were realized in $\mathrm{Zn}_{1-x} \mathrm{Mg}_{x} \mathrm{O} / \mathrm{MgO} / \mathrm{ZnO}$ with low $\mathrm{Mg}$ composition by inserting of a thin $(1 \mathrm{~nm}) \mathrm{MgO}$ obviously. The sample shows a high Hall mobility of $3090 \mathrm{~cm}^{2} / \mathrm{Vs}$ at $10 \mathrm{~K}$ and $332 \mathrm{~cm}^{2} / \mathrm{Vs}$ at RT. The carrier concentration reached a value as high as $1.1 \times 10^{13} \mathrm{~cm}^{-2}$. However, the study for higher $\mathrm{Mg}$ content $\mathrm{Zn}_{1-x} \mathrm{Mg}_{x} \mathrm{O} / \mathrm{MgO} / \mathrm{ZnO}$ structures will be done in the future. The results demonstrate a well defined heterostructure and the possibility for fabrication of $\mathrm{ZnMgO} / \mathrm{MgO} / \mathrm{ZnO}$ HEMT devices.

\section{Conflict of Interests}

The authors declare that there is no conflict of interests regarding the publication of this paper.

\section{Acknowledgments}

This work was supported by Project 863 of Xi'an Jiaotong University (2013AA03A101) and National Natural Science Foundation of China (no. 60876042 and no. 61176018).

\section{References}

[1] J. D. Albrecht, P. P. Ruden, S. Limpijumnong, W. R. L. Lambrecht, and K. F. Brennan, "High field electron transport properties of bulk ZnO," Journal of Applied Physics, vol. 86, no. 12, pp. 6864-6867, 1999.

[2] A. Ohtomo, M. Kawasaki, T. Koida et al., " $\mathrm{Mg}_{x} \mathrm{Zn}_{1-x} \mathrm{O}$ as a IIVI widegap semiconductor alloy," Applied Physics Letters, vol. 72, no. 19, pp. 2466-2468, 1998.

[3] A. Ohtomo, M. Kawasaki, I. Ohkubo, H. Koinuma, T. Yasuda, and Y. Segawa, "Structure and optical properties of $\mathrm{ZnO} /$ $\mathrm{Mg}_{0.2} \mathrm{Zn}_{0.8} \mathrm{O}$ superlattices," Applied Physics Letters, vol. 75, no. 7, pp. 980-982, 1999.

[4] H. Tampo, H. Shibata, K. Maejima et al., "Polarization-induced two-dimensional electron gases in $\mathrm{ZnMgO} / \mathrm{ZnO}$ heterostructures," Applied Physics Letters, vol. 93, no. 20, Article ID 202104, 3 pages, 2008.

[5] A. Tsukazaki, A. Ohtomo, M. Kawasaki et al., "Spin susceptibility and effective mass of two-dimensional electrons in $\mathrm{Mg}_{x} \mathrm{Zn}_{1-x} \mathrm{O} / \mathrm{ZnO}$ heterostructures," Physical Review B, vol. 78, no. 23, Article ID 233308, 2008.

[6] S. Sasa, M. Ozaki, K. Koike, M. Yano, and M. Inoue, "High-performance $\mathrm{ZnO} / \mathrm{ZnMgO}$ field-effect transistors using a heterometal-insulator-semiconductor structure," Applied Physics Letters, vol. 89, no. 5, Article ID 053502, 2006.
[7] K. Koike, D. Takagi, M. Kawasaki et al., "Ion-sensitive characteristics of an electrolyte-solution-gate $\mathrm{ZnO} / \mathrm{ZnMgO}$ heterojunction field-effect transistor as a biosensing transducer," Japanese Journal of Applied Physics, vol. 46, no. 36-40, pp. L865-L867, 2007.

[8] K. Koike, D. Takagi, M. Hashimoto et al., "Characteristics of enzyme-based $\mathrm{ZnO} / \mathrm{Zn}_{0.7} \mathrm{Mg}_{0.3} \mathrm{O}$ heterojunction field-effect transistor as glucose sensor," Japanese Journal of Applied Physics, vol. 48, no. 4, Article ID 04C081, 2009.

[9] M. Nakano, A. Tsukazaki, A. Ohtomo et al., "Electronic-field control of two-dimensional electrons in polymer-gated-oxide semiconductor heterostructures," Advanced Materials, vol. 22, no. 8, pp. 876-879, 2010.

[10] J. D. Ye, S. Pannirselvam, S. T. Lim et al., "Two-dimensional electron gas in $\mathrm{Zn}$-polar $\mathrm{ZnMgO} / \mathrm{ZnO}$ heterostructure grown by metal-organic vapor phase epitaxy," Applied Physics Letters, vol. 97, no. 11, Article ID 111908, 2010.

[11] H.-A. Chin, I.-C. Cheng, C.-K. Li et al., "Electrical properties of modulation-doped rf-sputtered polycrystalline $\mathrm{MgZnO} / \mathrm{ZnO}$ heterostructures," Journal of Physics D: Applied Physics, vol. 44, no. 45, Article ID 455101, 4 pages, 2011.

[12] A. Tsukazaki, H. Yuji, S. Akasaka et al., "High electron mobility exceeding $10^{4} \mathrm{Cm}^{2} \mathrm{v}^{-1} \mathrm{~s}^{-1}$ in $\mathrm{Mg}_{x} \mathrm{Zn}_{1-x} \mathrm{O} / \mathrm{ZnO}$ single heterostructures grown by molecular beam epitaxy," Applied Physics Express, vol. 1, no. 5, Article ID 055004, 2008.

[13] H. Tampo, H. Shibata, K. Matsubara et al., "Two-dimensional electron gas in $\mathrm{Zn}$ polar $\mathrm{ZnMgO} / \mathrm{ZnO}$ heterostructures grown by radical source molecular beam epitaxy", Applied Physics Letters, vol. 89, no. 13, Article ID 132113, 3 pages, 2006.

[14] M. Miyoshi, T. Egawa, H. Ishikawa et al., "Nanostructural characterization and two-dimensional electron-gas properties in high-mobility $\mathrm{AlGaN} / \mathrm{AlN} / \mathrm{GaN}$ heterostructures grown on epitaxial AlN/sapphire templates," Journal of Applied Physics, vol. 98, no. 6, Article ID 063713, 5 pages, 2005.

[15] I. P. Smorchkova, L. Chen, T. Mates et al., "AlN/GaN and (Al,Ga)N/AlN/GaN two-dimensional electron gas structures grown by plasma-assisted molecular-beam epitaxy," Journal of Applied Physics, vol. 90, no. 10, pp. 5196-5201, 2001.

[16] L. Shen, S. Heikman, B. Moran et al., "AlGaN/AlN/GaN highpower microwave HEMT," IEEE Electron Device Letters, vol. 22, no. 10, pp. 457-459, 2001.

[17] L. Hsu and W. Walukiewicz, "Effect of polarization fields on transport properties in AlGaN/GaN heterostructures," Journal of Applied Physics, vol. 89, no. 3, pp. 1783-1789, 2001.

[18] Z. X. Mei, Y. Wang, X. L. Du et al., "Controlled growth of Opolar $\mathrm{ZnO}$ epitaxial film by oxygen radical preconditioning of sapphire substrate," Journal of Applied Physics, vol. 96, no. 12, pp. 7108-7111, 2004

[19] H. Tampo, H. Shibata, K. Maejima et al., "Strong excitonic transition of $\mathrm{Zn}_{1-x} \mathrm{Mg}_{x} \mathrm{O}$ alloy," Applied Physics Letters, vol. 91, no. 26, Article ID 261907, 3 pages, 2007.

[20] J. S. Park, S. K. Hong, T. Minegishi et al., "Polarity control of $\mathrm{ZnO}$ films on (0001) $\mathrm{Al}_{2} \mathrm{O}_{3}$ by $\mathrm{Cr}$-compound intermediate layers," Applied Physics Letters, vol. 90, no. 20, Article ID 201907, 3 pages, 2007.

[21] R. Dingle, H. L. Störmer, A. C. Gossard, and W. Wiegmann, "Electron mobilities in modulation-doped semiconductor heterojunction superlattices," Applied Physics Letters, vol. 33, no. 7, pp. $665-667,1978$. 
[22] S. Hiyamizu, T. Mimura, T. Fujii, and K. Nanb, "High mobility of two-dimensional electrons at the GaAs/n-AlGaAs heterojunction interface," Applied Physics Letters, vol. 37, no. 9, pp. 805-807, 1980.

[23] S. hiyamizu and T. Mimura, "High mobility electrons in selectively doped GaAs/n-AlGaAs heterostructures grown by $\mathrm{MBE}$ and their application to high-speed devices," Journal of Crystal Growth, vol. 56, no. 2, pp. 455-463, 1982.

[24] M. A. Khan, J. M. Van Hove, J. N. Kuznia, and D. T. Olson, "High electron mobility $\mathrm{GaN} / \mathrm{Al}_{x} \mathrm{Ga}_{1-x} \mathrm{~N}$ heterostructures grown by low-pressure metalorganic chemical vapor deposition," Applied Physics Letters, vol. 58, no. 21, pp. 2408-2410, 1991.

[25] M. A. Khan, J. N. Kuznia, J. M. Van Hove, N. Pan, and J. Carter, "Observation of a two-dimensional electron gas in low pressure metalorganic chemical vapor deposited GaN$\mathrm{Al}_{x} \mathrm{Ga}_{1-x} \mathrm{~N}$ heterojunctions," Applied Physics Letters, vol. 60, no. 24, pp. 3027-3029, 1992.

[26] T. Edahiro, N. Fujimura, and T. Ito, "Formation of twodimensional electron gas and the magnetotransport behavior of $\mathrm{ZnMnO} / \mathrm{ZnO}$ heterostructure," Journal of Applied Physics, vol. 93, no. 10, pp. 7673-7675, 2003.

[27] K. Koike, K. Hama, I. Nakashima et al., "Piezoelectric carrier confinement by lattice mismatch at $\mathrm{ZnO} / \mathrm{Zn}_{0.6} \mathrm{Mg}_{0.4} \mathrm{O}$ heterointerface," Japanese Journal of Applied Physics, vol. 43, no. 10, pp. L1372-L1375, 2004.

[28] O. Ambacher, B. Foutz, J. Smart et al., "Two dimensional electron gases induced by spontaneous and piezoelectric polarization in undoped and doped AlGaN/GaN heterostructures," Journal of Applied Physics, vol. 87, no. 1, pp. 334-344, 2000.

[29] I. P. Smorchkova, C. R. Elsass, J. P. Ibbetson et al., "Polarizationinduced charge and electron mobility in AlGaN/GaN heterostructures grown by plasma-assisted molecular-beam epitaxy," Journal of Applied Physics, vol. 86, no. 8, pp. 4520-4526, 1999.

[30] E. T. Yu, G. J. Sullivan, P. M. Asbeck, C. D. Wang, D. Qiao, and S. S. Lau, "Measurement of piezoelectrically induced charge in GaN/AlGaN heterostructure field-effect transistors," Applied Physics Letters, vol. 71, no. 19, pp. 2794-2796, 1997.

[31] M. Yano, Zinc Oxide, Bulk, Thin Films and Nanostructures, C. Jagadish and S. J. Pearton, Eds., Elsevier, Amsterdam, The Netherlands, 2006. 

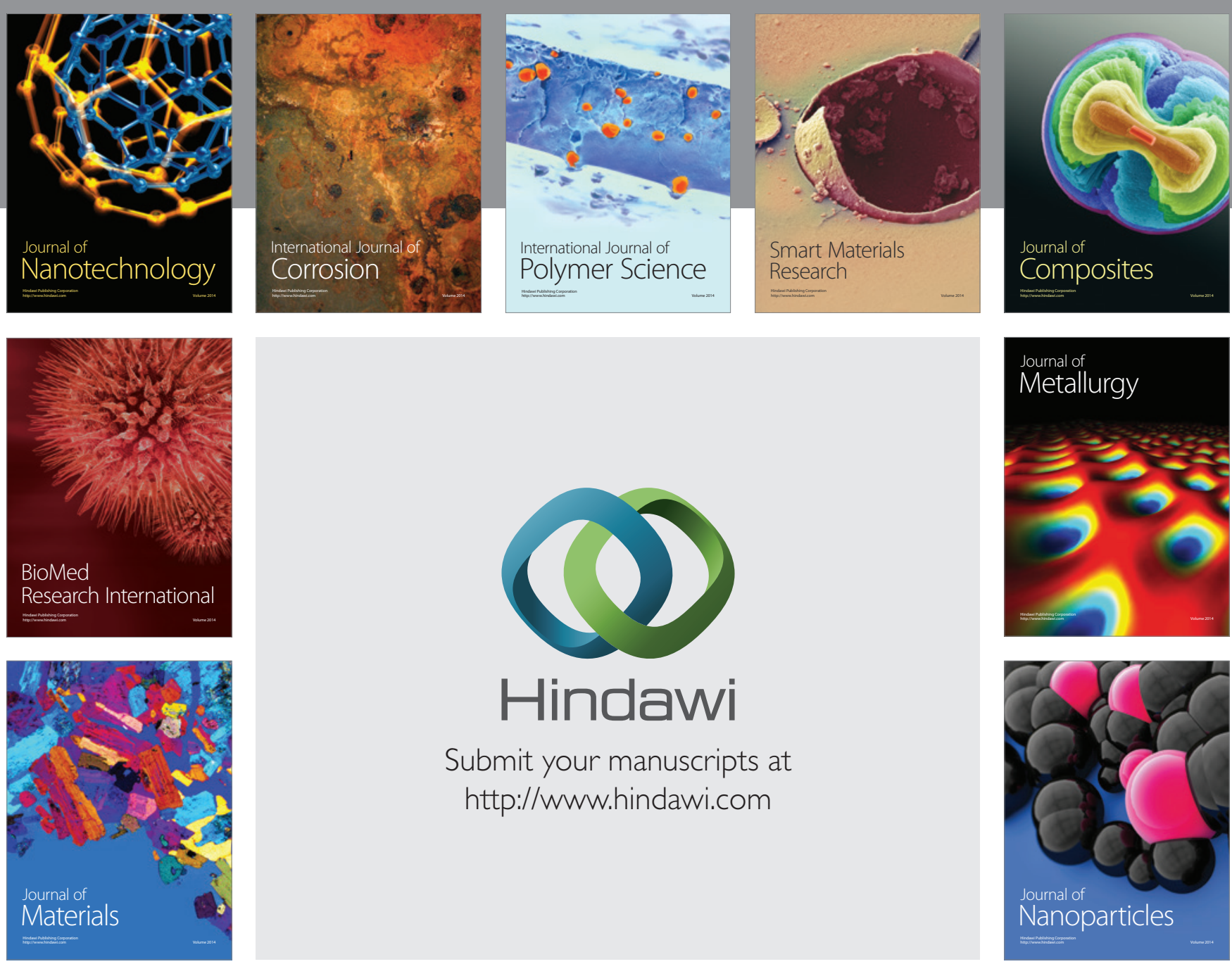

Submit your manuscripts at http://www.hindawi.com
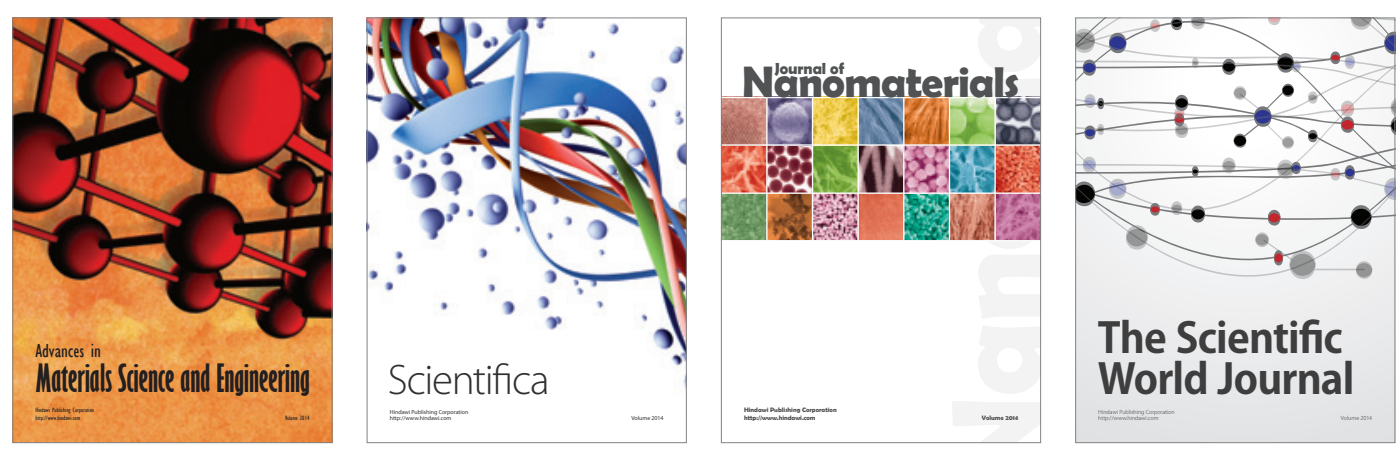

\section{The Scientific World Journal}
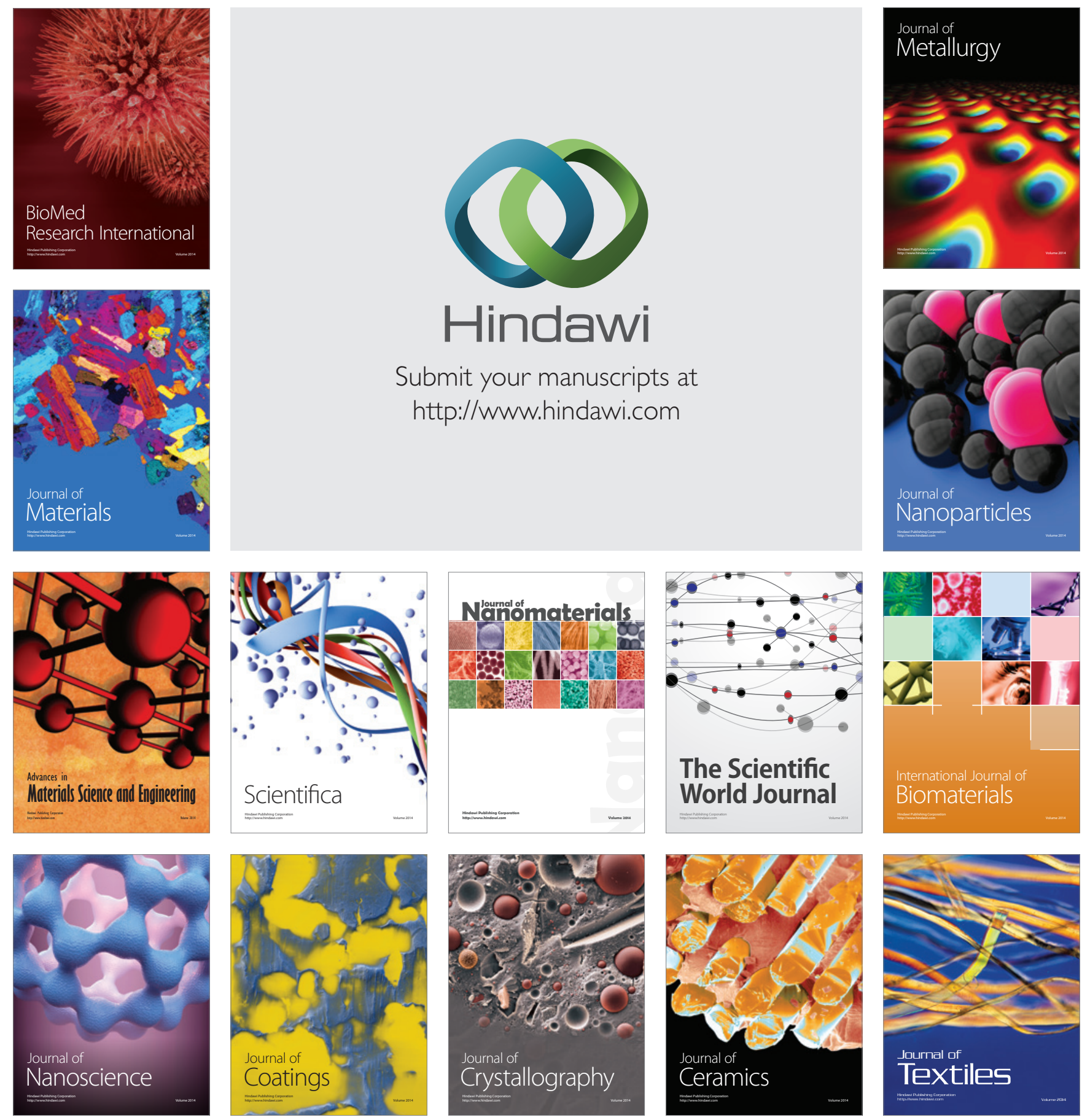